\title{
FLUKTUASI KURS RUPIAH TERHADAP DOLLAR AMERIKA SERIKAT PADA PERIODE TAHUN 1997.I - 2004.IV
}

\author{
Anggyatika Mahda Kurnia ${ }^{1}$ \\ Didit Purnomo ${ }^{1}$ \\ ${ }^{1}$ Fakultas Ekonomi Universitas Muhammadiyah Surakarta \\ E-mail: didiet_p@yahoo.com
}

\begin{abstract}
This study aimed to analyze the fluctuation of the rupiah against the U.S. dollar. The data used in this study are quarterly time series data between the 1997.I to 2004.IV. Analysis tool used in this study is multiple linear regressions using the Error Correction Model (ECM). The results of this study concluded that variables such as exchange rates, inflation, SBI rate and the value of imports is stationary, only money supply variable that is not stationary. Based on the classical assumption was not found problem. Normality test showed normal distribution of Ut, tests of model specification with the Ramsey Reset test indicates the model used is linear. The coefficient of determination (R2) showed that approximately 90.5813 percent of the value of the rupiah against the U.S. dollar be explained by variables in the model. Result analysis by t test found that a significant variable is the money supply, inflation, and the value of imports.
\end{abstract}

Key word: causality, ECM, free floating, money demand

\section{PENDAHULUAN}

Globalisasi dalam bidang ekonomi, sebagai contoh menyebabkan berkembangnya sistem perekonomian ke arah yang lebih terbuka antar Negara. Perekonomian terbuka inilah yang membawa suatu dampak ekonomis yaitu terjadinya perdagangan internasional antar negara-negara di dunia. Dengan adanya perdagangan internasional inilah maka akan dijumpai masalah baru yakni perbedaan mata uang yang digunakan oleh negara-negara yang bersangkutan. Akibat adanya perbedaan mata uang yang digunakan baik di negara yang menjadi pengimpor maupun pengekspor maka menimbulkan suatu perbedaan nilai tukar mata uang (kurs), oleh karena itu diper- lukan penukaran mata uang antarnegara.

Perbedaan nilai tukar mata uang suatu negara (kurs) pada prinsipnya ditentukan oleh besarnya permintaan dan penawaran mata uang tersebut (Levi, 1996:129). Kurs merupakan salah satu harga yang lebih penting dalam perekonomian terbuka, mengingat pengaruhnya yang besar bagi neraca transaksi berjalan maupun bagi variabel-variabel makro ekonomi lainnya. Kurs dapat dijadikan alat untuk mengukur kondisi perekonomian suatu negara. Pertumbuhan nilai mata uang yang stabil menunjukkan bahwa negara tersebut memiliki kondisi ekonomi yang relatif baik atau stabil.

Krisis sektor keuangan (sektor finansial) 
di Indonesia yang dimulai pada bulan Agustus 1997 lalu di mana krisis ini ditandai dengan terjadinya krisis nilai tukar, merupakan suatu fenomena yang dapat dijadikan contoh yang kongkrit bagaimana krisis pada sektor finansial dapat menjadi pemicu krisis ekonomi secara keseluruhan. Setelah krisis terjadi, nilai rupiah mengalami penurunan yang sangat drastis yang menyebabkan kondisi ekonomi Indonesia melemah. Nilai tukar rupiah secara simultan mendapat tekanan yang cukup berat karena besarnya capital out flow akibat hilangnya kepercayaan investor asing terhadap prospek perekonomian Indonesia.

Fluktuasi nilai tukar ini bagi sebagian orang dianggap sebagi salah satu penyebab terjadinya krisis ekonomi di Indonesia. Ketidakstabilan nilai tukar ini mempengaruhi arus modal atau investasi dan perdagangan internasional. Indonesia sebagai negara yang banyak mengimpor bahan baku industri mengalami dampak dari ketidakstabilan kurs ini, yang dapat dilihat dari melonjaknya biaya produksi sehingga menyebabkan harga barang-barang milik Indonesia mengalami peningkatan. Dengan melemahnya kurs rupiah menyebabkan perekonomian Indonesia menjadi goyah dan dilanda krisis ekonomi dan kepercayaan terhadap mata uang dalam negeri.

Mengingat besarnya dampak dari fluktuasi kurs terhadap perekonomian ini maka jelas diperlukan suatu manajemen kurs yang baik sehingga kurs menjadi stabil dan fluktuasinya dapat diprediksi, sehingga pasar maupun otoritas moneter mampu melakukan langkah-langkah anti positif meredam dampak negatif berfluktuasinya kurs terhadap perekonomian sehingga perekonomian dapat tetap berjalan dengan stabil, sehingga jika terjadi kegagalan pada manajemen kurs maka hal tersebut merupakan gangguan terhadap ketidakstabilan perekonomian yang akan berdampak luas kepada proses pembangunan ekonomi secara keseluruhan.

Penerapan sistem devisa bebas dan ditambah dengan penerpan sistem nilai tukar mengambang (free floating) di Indonesia sejak tahun 1997, menyebabkan pergerakan nilai tukar di pasar menjadi sangat rentan oleh pengaruh faktor-faktor ekonomi dengan non ekonomi. Sebagai contoh pertumbuhan nilai mata uang rupiah terhadap dolar AS pada era sebelum krisis melanda Indonesia dan kawasan Asia lainnya masih relatif stabil. Jika dibandingkan dengan masa sebelum krisis, semenjak krisis ini terjadi ada lonjakan kurs dolar AS ada diantara Rp.6.700-Rp 9.530 sedangkan periode 1981-1996 di bawah Rp. 2.500 (Bank Indonesia, 2000).

Pergerakan nilai dolar AS dapat dibacakan sebagai determinan utama nilai rupiah. Dan melalui mekanisme transmisi ini, inflasi serta suku bunga domestik juga turun ke tingkat terendah dalam sejarah. Sebaliknya, dengan menguatnya dolar AS belakangan ini, nilai rupiah merosot serta ada potensi besar inflasi meningkat. Pergerakan nilai tukar yang fluktuatif ini mempengaruhi perilaku masyarakat dalam memegang uang, selain faktor-faktor yang lain seperti tingkat suku bunga dan inflasi. Kondisi ini didukung oleh laju inflasi yang meningkat tajam dan menurunnya kepercayaan masyarakat terhadap perbankan nasional. Permintaan uang merupakan permintaan atas saldo kas riil dari masyarakat. Pendekatan yang dapat digunakan untuk melihat perilaku permintaan uang adalah perkembangan dari uang kartal dan uang giral (M1). Pada awal tahun 1998, MI atau sering disebut dengan uang dalam arti 
sempit mengalami peningkatan yang tajam sekitar 26,17 persen dari tahun sebelumnya, sebagai akibat naiknya nilai tukar rupiah (Bank Indonesia, 1998).

Tingkat suku bunga yang tinggi menarik jumlah uang yang beredar dimasyarakat. Jika tingkat suku bunga dinaikkan, jumlah uang yang beredar berkurang karena orang lebih senang menabung daripada memutarkan uangnya pada sektor-sektor produktif. Sebaliknya jika tingkat suku bunga terlalu rendah maka jumlah uang yang beredar dimasyarakat akan bertambah karena orang lebih suka memutarkan uang pada sektor-sektor produktif daripada untuk menabung. Dalam hal ini tingkat suku bunga merupakan instrument konvensional untuk mengendalikan inflasi (Khalwaty, 2000:144).

Inflasi menyebabkan harga barang impor lebih murah daripada barang yang di hasilkan di dalam negeri. Maka pada umumnya inflasi akan menyebabkan impor berkembang lebih cepat tetapi sebaliknya perkembangan ekspor akan bertambah lambat. Di samping itu aliran modal keluar akan lebih banyak daripada yang masuk kedalam negeri. Berbagai kecenderungan ini akan memperburuk keadaan neraca perdagangan, maka deficit neraca perdagangan yang serius mungkin berlaku. Hal ini seterusnya akan menimbulkan kemerosotan nilai mata uang (Sukirno, 2000: 308).

Untuk menjaga kestabilan nilai rupiah bank sentral telah mengambil berbagai kebijakan dengan melihat faktor ekonomi apa yang menyebabkan nilai tukar rupiah melemah. Kestabilan kurs rupiah ini dicapai melalui analisis fundamental dengan melihat faktor-faktor yang mempengaruhi nilai tukar rupiah terutama faktor-faktor ekonomi. Pada periode krisis ini bank sentral mengambil kebijakan untuk lebih mengetatkan moneter melalui kenaikan tingkat bunga SBI, sementara pemerintah menyatakan langkah stabilisasi rupiah ditempuh dengan sinkronisasi fiskal moneter. Ini berarti BI akan terus berusaha melakukan intervensi untuk menahan fluktuasi (Bank Indonesia, 2000).

Faktor-faktor fundamental ekonomi apa yang mempengaruhi fluktuasi kurs rupiah terhadap dolar AS dan seberapa besar efektifitas kebijakan dari analisis fundamental faktor-faktor ekonomi tersebut terhadap kurs rupiah selama dan sesudah masa krisis akan menjadi fokus dalam penelitian ini. Dalam penelitian ini diambil beberapa faktor yang dapat mempengaruhi nilai tukar atau kurs rupiah di antaranya adalah jumlah uang beredar, tingkat inflasi, tingkat suku bunga SBI, dan nilai impor.

Teori Kurs tentang Law of One Price (Dalil Satu Harga). Dalil ini menyatakan bahwa dalam pasar yang kompetitif, yang bebas dari bahaya transportasi dan berbagai hambatan resmi dalam perdagangan, barangbarang identik, harga jual barang tersebut adalah sama untuk berbagai negara (dalam arti jika menggunakan mata uang yang sama). Dengan kata lain bahwa sama dimanapun transaksi perdagangan itu berlangsung. Dalil satu harga jika dinyatakan adalah sebagai berikut:

$\mathrm{P}_{\mathrm{Rp}}^{\mathrm{i}}=\left(\mathrm{E}_{\mathrm{Rp} / \mathrm{S}}\right) \times\left(\mathrm{P}_{\mathrm{US}}^{\mathrm{i}}\right)$

dimana $\mathrm{P}_{\mathrm{Rp}}^{\mathrm{i}}$ adalah harga rupiah dari barang $\mathrm{i}$ apabila dijual di Indonesia dan $\mathrm{P}_{\text {US }}^{\mathrm{i}}$ adalah harga dolar dari barang i jika dijual di Amerika. Berdasarkan persamaan (1) maka kurs Rupiah/Dolar (Rp/\$) adalah sebagai berikut:

$E_{R p / \$}=P_{R p}^{i} / P_{U S}^{i}$ 
Teori Kurs tentang Purchasing Power Parity. Dalam teori ini dijelaskan bahwa perbandingan nilai satu mata uang dengan mata uang Negara lainnya ditentukan oleh tingkat harga di masing-masing negara. Teori paritas daya beli (Purchasing Power Parity) memperkirakan bahwa penurunan dalam daya beli mata uang domestik, yang ditandai oleh meningkatnya harga di dalam negeri, akan diikuti oleh depresiasi mata uang domestik dan juga sebaliknya. PPP memperkirakan nilai kurs antara rupiah dengan dolar adalah sebagai berikut:

$E_{R p / \$}=P_{R p} / P_{s}$

Dengan demikian teori Paritas Daya Beli (PPP) menyatakan bila diukur dalam satuan mata uang yang sama maka semua tingkat harga dari seluruh negara adalah sama (Krugman, 1999: 121). Persamaan (3) disebut sebagai PPP relatif menyatakan bahwa perubahan persentase kurs antara dua mata uang pada periode tertentu sama dengan selisih antara persentase perubahan tingkat-tingkat harga di berbagai negara. PPP relatif menjelaskan harga-harga dan kurs mengalami perubahan sehingga nisbah daya beli dalam negeri dan luar negeri tiap negara tetap bertahan.

Teori Kurs tentang Interest Parity (Paritas Suku Bunga). Kondisi paritas suku bunga (interest parity) adalah suatu kondisi dimana perkiraan imbalan yang ditawarkan semua simpanan dalam berbagai mata uang asing/valuta asing sama (jika dihitung dengan menggunakan mata uang yang sama). Teori ini menyatakan perbedaan persentase antara nilai tukar forward dan untuk nilai tukar spot sama dengan perbedaan di dalam tingkat bunga untuk surat-surat berharga di kedua negara. Pada kondisi seperti ini maka pasar tidak akan mengalami kelebihan penawaran simpanan tertentu dan kelebihan permintaan simpanan untuk mata uang lainnya. Oleh karena itu dapat disimpulkan bahwa pasar valuta asing akan mencapai keseimbangan apabila kondisi paritas suku bunga (interest party) tercipta (Yuliati, 1998:100).

Perekonomian terbuka menimbulkan adanya tukar menukar barang antar negara yang didalamnya terdapat perbandingan nilai tukar antar negara-negara yang melakukan pertukaran. Nilai tukar ini merupakan suatu harga dalam pertukaran tersebut. Dengan pertukaran inilah timbul perbandingan mata uang antar negara tersebut. Perbandingan nilai inilah yang sering disebut dengan kurs (Exchange Rate) (Nopirin, 1992:163). Dalam melakukan pertukaran inilah suatu Negara harus memiliki satu mata uang yang menunjukkan harga dari setiap barang dan jasa yang diproduksinya. Kurs memegang peranan dalam hubungan perdagangan internasional, karena kurs dapat membandingkan harga dari setiap barang dab jasa yang dihasilkan oleh suatu negara. Nilai tukar mata uang atau kurs antara dua mata uang adalah sama dengan jumlah rupiah yang diperlukan untuk membeli satu dolar atau dengan kata lain merupakan nilai rupiah dalam mata uang dolar (Levi, 2001:26).

Kurs rupiah terhadap dolar AS memainkan peranan sentral dalam perdagangan internasional, karena kurs rupiah terhadap dolar AS memungkinkan kita untuk membandingkan harga-harga segenap barang dan jasa yang dihasilkan berbagai negara. Kurs valuta asing dapat diklarifikasikan ke dalam kurs jual dan kurs beli. Selisih dari penjualan dan pembelian merupakan pendapatan bagi pedagang valuta asing. Sedangkan bila ditin- 
jau dari waktu yang di butuhkan dalam penyerahan valuta asing setelah terjadi transaksi, kurs dapat diklarifikasikan dalam kurs spot dan kurs berjalan (forward exchange). Semua transaksi valuta asing yang berlangsung seketika atau langsung dimana kedua pihak sepakat untuk saling membayar secepatnya saat itu atau paling lambat dua hari setelah transaksi. Kurs yang melandasi perdagangan seketika (on the spot) disebut kurs spot (spot exchange rate) sedangkan kesepakatannya disebut transaksi spot. Beberapa kesepakatan seringkali secara khusus menetapkan suatu tanggal lebih dari dua hari, misalnya 30 hari, 90 hari, atau 180 hari, atau bahkan beberapa tahun. Kurs yang menjadi besar bagi transaksi semacam itu disebut kurs berjangka (forward exchange). Kurs spot dan kurs forward memang tidak selalu sama tetapi fluktuasinya selalu seiring (Krugman, 1999).

Kurs dan Faktor-faktor yang Mempengaruhinya. Bahwa perubahan reserve valuta asing (neraca pembayaran) timbul sebagai akibat kelebihan permintaan atau penawaran uang. Apabila terdapat kelebihan jumlah uang beredar maka neraca pembayaran akan defisit dan sebalikya apabila terdapat kelebihan permintaan uang, neraca pembayaran akan surplus kelebihan jumlah uang beredar akan mengakibatkan masyarakat membelanjakan kelebihan ini, misalnya untuk impor atau membeli surat-surat berharga luar negeri sehingga terjadi aliran modal keluar, yang berarti makin besar permintaan akan valas naik dan mata uang sendiri turun (Nopirin, 1997:222). Jika pemerintah menambah uang beredar akan menurunkan tingkat bunga dan merangsang untuk investasi keluar negeri dan terjadi aliran modal keluar, kurs valuta asing naik (apresiasi). Dengan menaiknya penawaran uang atau jumlah uang beredar akan menaikkan harga barang yang diukur dengan (term of money) sekaligus akan menaikkan harga valuta asing yang diukur dengan mata uang domestik (Herlambang, dkk, 2001).

Nilai tukar dibedakan menjadi dua yaitu nilai tukar nominal dan nilai tukar riil. Nilai tukar nominal menunjukkan harga relatif mata uang dari dua negara, sedangkan nilai tukar riil menunjukkan tingkat ukuran (rate) suatu barang dapat diperdagangkan antar negara. Jika nilai tukar riil tinggi berarti harga produk luar negeri relatif murah dan haga produk domestik relatif mahal. Persentase perubahan nilai tukar nominal sama dengan pesentase perubahan nilai tukar riil ditambah perbedaan inflasi antara inflasi luar negeri dan inflasi domestik (persentase perubahan harga inflasi). Jika suatu negara luar negeri lebih tinggi inflasinya dibandingkan domestik (Indonesia) maka rupiah akan ditukarkan dengan lebih banyak valas. Jika inflasi meningkat untuk membeli valuta asing yang sama jumlahnya harus di tukar dengan rupiah yang makin banyak atau depresiasi rupiah (Herlambang dkk, 2001: 282). Suatu mata uang dikatakan "kuat" apabila transaksi kredit lebih besar dari transaksi outonomous debit (surplus neraca pembayaran), sebaliknya dikatakan "lemah" apabila neraca pembayaran mengalami defisit. Selanjutnya, transaksi otonomus debit dan kredit dipengaruhi oleh faktor-faktor yang berasal dari dalam negeri maupun dari luar negeri. Di antaranya faktor harga atau inflasi akan menyebabkan impor naik dan ekspor turun yang akan mengakibatkan naiknya permintaan valuta asing. Akibat selanjutnya, kurs valuta asing akan naik (depresiasi mata uang sendiri) (Nopirin, 1997:148). 
Kebijakan yang dapat digunakan untuk mencapai sasaran stabilitas harga atau pertumbuhan ekonomi adalah kebijakan-kebijakan moneter dengan menggunakan instrument moneter (suku bunga atau agregat moneter). Salah satu jalur yang digunakan adalah jalur nilai tukar, berpendapat bahwa pengetatan moneter yang mendorong peningkatan suku bunga akan mengakibatkan apresiasi nilai tukar karena adanya pemasukan modal dari luar negeri. Hubungan antara suku bunga dengan nilai tukar dalam perekonomian terbuka di mana terdapat aliran atau arus lalu lintas modal secara bebas menjelaskan bahwa dengan adanya peningkatan suku bunga akan memperkuat nilai tukar yang disebabkan meningkatnya arus modal dari luar negeri (Arifin, 1998:8)
Di dalam pasar bebas perubahan kurs tergantung pada beberapa faktor yang mempengaruhi permintaan dan penawaran valuta asing. Bahwa valuta asing diperlukan guna melakukan transaksi pembayaran keluar negeri (impor). Makin tinggi tingkat pertumbuhan pendapatan (relatif terhadap negara lain) makin besar kemungkunan untuk impor yang berarti makin besar pula permintaan akan valuta asing. Kurs valuta asing cenderung meningkat dan harga mata uang sendiri turun. Demikian juga inflasi akan menyebabkan impor naik dan eksport turun kemudian akan menyebabkan valuta asing naik. (Nopirin, 1997:148)

Penelitian Terdahulu. Studi Empiris Mengenai Pengaruh Nilai Tukar Rupiah.

Tabel 1. Studi Empiris Mengenai Pengaruh Nilai Tukar Rupiah (Kurs)

\begin{tabular}{|c|c|c|c|c|}
\hline No & Nama & Judul & Variabel & Hasil penelitian \\
\hline 1 & $\begin{array}{l}\text { Levi lqbal } \\
\text { Adios } \\
\text { (2003) }\end{array}$ & $\begin{array}{l}\text { "Analisis Fluktuasi Kurs } \\
\text { Rupiah terhadap Dollar } \\
\text { AS". }\end{array}$ & $\begin{array}{l}\text { Dependen: } \\
\text { kurs } \\
\text { Independen } \\
\text { JUB, inflasi, tingkat } \\
\text { suku bunga SBI, } \\
\text { NPI }\end{array}$ & $\begin{array}{l}\text { Dengan menggunakan metode ECM dapat } \\
\text { dijelaskan bahwa variabel JUB tidak mem- } \\
\text { pengaruhi kurs rupiah, sedangkan variabel } \\
\text { inflasi, SBI dan NPI mempunyai pengaruh } \\
\text { signifikan terhadap kurs rupiah }\end{array}$ \\
\hline 2 & $\begin{array}{l}\text { Eni } \\
\text { Setyawati } \\
\text { dan } \\
\text { Soepatini } \\
\text { (2004) }\end{array}$ & $\begin{array}{l}\text { "Analisis Faktor-faktor } \\
\text { yang mempengaruhi } \\
\text { Nilai Tukar Rupiah } \\
\text { Terhadap Dolar AS } \\
\text { Dengan Pendapatan } \\
\text { Neraca Pembayaran". }\end{array}$ & $\begin{array}{l}\text { Dependen: } \\
\text { Kurs } \\
\text { Independen } \\
\text { Seku bunga, PDB, } \\
\text { JUB, harga relatif }\end{array}$ & $\begin{array}{l}\text { Variabel tingkat suku bunga dan PDB } \\
\text { berpengaruh dan signifikan dalam jangka } \\
\text { pendek. Variabel JUB dan harga relative } \\
\text { berpengaruh dan signifikan dalam jangka } \\
\text { panjang. }\end{array}$ \\
\hline 3 & $\begin{array}{l}\text { Nastain } \\
(2003)\end{array}$ & $\begin{array}{l}\text { "Analisis Pengaruh } \\
\text { Pendapatan Nasional } \\
\text { Laju Inflasi, Tingkat } \\
\text { Suku Bunga, dan } \\
\text { Jumlah Uang Beredar } \\
\text { Terhadap Nilai Tukar } \\
\text { Rupiah Terhadap Dollar } \\
\text { AS Periode 1985-2001". }\end{array}$ & $\begin{array}{l}\text { Dependen : } \\
\text { Kurs } \\
\text { Independent } \\
\text { Pendapatan } \\
\text { Nasional, laju inflasi, } \\
\text { tingkat suku bunga, } \\
\text { jumlah uang beredar }\end{array}$ & $\begin{array}{l}\text { Dengan menggunakan metode OLS diperoleh } \\
\text { hasil bahwa variabel pendapatan nasional dan } \\
\text { tingkat suku bunga tidak berpengaruh secara } \\
\text { signifikan terhadap kurs rupiah, sedangkan } \\
\text { variabel jumlah uang beredar dan inflasi } \\
\text { berpengaruh signifikan terhadap kurs rupiah. }\end{array}$ \\
\hline 4 & $\begin{array}{l}\text { Didiet } \\
\text { Purnomo } \\
\text { dan } \\
\text { Wahyudi } \\
\text { (2003) }\end{array}$ & $\begin{array}{l}\text { "Hubungan Kausalitas } \\
\text { Defisit Neraca Transaksi } \\
\text { Berjalan Dengan Kurs Di } \\
\text { Indonesia". }\end{array}$ & $\begin{array}{l}\text { Variabel : } \\
\text { Kurs } \\
\text { Defisit neraca tran- } \\
\text { saksi berjalan }\end{array}$ & $\begin{array}{l}\text { Dengan menggunakan unji kausalitas Granger } \\
\text { dapat disimpulkan bahwa mekanisme } \\
\text { perubahan kurs tidak mempengaruhi perubahan } \\
\text { deficit neraca transaksi berjalan, akan tetapi } \\
\text { mekanisme perubahan deficit neraca transaksi } \\
\text { berjalan mempengaruhi perubahan kurs. }\end{array}$ \\
\hline
\end{tabular}


Koefisien determinasi $\left(\mathrm{R}^{2}\right)$ menunjukkan bahwa penelitian variabel penelitian sudah tepat, karena nilai $\mathrm{R}^{2}$ yang dihasilkan hampir mencapai angka 1 . nilai koefisien determinasi sebesar 0,905813 yang menunjukkan bahwa sekitar 0,905813\% variabel kurs rupiah dijelaskan oleh jumlah uang beredar, inflasi, tingkat suku bunga SBI dan nilai impor. Sedangkan sisanya yaitu $9,4187 \%$ dijelaskan oleh variabel-variabel diluar model.

Hasil analisis dengan uji t diketahui bahwa variabel yang mempunyai pengaruh yang signifikan adalah jumlah uang beredar pada $\alpha=0,10$, inflasi pada $\alpha=0,01$, nilai impor pada $\alpha=0,01$ terhadap kurs rupiah terhadap dolar AS. Sedangkan variabel yang tidak mempunyai pengaruh signifikan adalah tingkat suku bunga SBI terhadap kurs rupiah terhadap dolar AS.

Variabel ECT signifikan pada tingkat signifikan $\alpha=0,05$ dengan nilai koefisien regresi sebesar 0,231835.

\section{DAFTAR PUSTAKA}

Bank Indonesia, Berbagai Edisi, Statistik Ekonomi-Keuangan Indonesia, Jakarta: Bank Indonesia.

Bank Indonesia, Berbagi Edisi, Laporan Tahunan, Jakarta: Bank Indonesia.

Arifin, Samsjul. 1998. Buletin Ekonomi Moneter dan Perbankan, Vol. 1 No. 3, Desember.

Boediono, 1990. Ekonomi Internasional: Seri Sinopsis Pengantar Ilmu Ekonomi, Edisi Pertama, Yogyakarta: BPFE.

Boediono, 2000. Ekonomi Mikro, Yogyakarta: BPFE.

Gujarati, Damodar, 1995. Ekonometrika Dasar. Jakarta: Erlangga.
Gujarati, Damodar, 1997. Ekonometrika Dasar. Jakarta: Erlangga.

Gujarati, Damodar, 2002. Ekonometrika Dasar. Jakarta: Erlangga.

Herlambang, Sugiarto, Brastoro Said Kelana, 2001. Ekonomi Makro: Teori Analisis dan Kebijakan. Jakarta: Gramedia Pustaka Utama.

Iswatini, Fidya. 2003. Analisis Nilai Tukar Rupiah terhadap Dollar AS dan Faktorfaktoryang Mempengaruhinya. Skripsi tidak diterbitkan. Surakarta: Universitas Muhammadiyah Surakarta.

Khalwaty, Tajul, 2000. Inflasi dan Solusinya. Jakarta:PT. Gramedia Pustaka Utama.

Krugman, Paul R and Maurice Obstfeld, 1999. Ekonomi Internasional: Teori dan Kebijakan Edisi Kedua Alih Bahasa oleh Haris Munandar dan Faisal Basri, Jakarta: Raja Grafindo Persada.

Kuncoro, Mudrajad, 1996. Manajemen Keuangan Internasional, Edisi Pertama, Yogyakarta: BPFE.

Levi, Maurice D. 1996. Keuangan Internasional. Yogyakarta: Andi Offset

Levi, Maurice D. 2001. Keuangan Internasional. Yogyakarta: Andi Offset.

Nastain. 2003. Analisis Pengaruh Pendapatan Nasional, Laju Inflasi, Tingkat Suku Bunga dan Jumlah Uang Beredar Terhadap Nilai Tukar Rupiah Terhadap Dollar AS Periode 1985-2001.Skripsi tidak diterbitkan. Surakarta: UMS.

Nopirin. 1992. Ekonomi Moneter. Buku II. Yogyakarta: BPFE.

Nopirin. 1997. Ekonomi Moneter. Buku I. Yogyakarta: BPFE.

Purnomo, Didit dan Wahyudi. 20003. Hubu- 
ngan Kausalitas Defisit Neraca Transaksi Berjalan dengan Kurs di Indonesia. Jurnal Ekonomi Pembangunan FE UMS, Vol. 4 No. 1, Juni.

Santoso, Ruddy Tri. 1994. Pembiayaan Transaksi Luar Negeri. Yogyakarta: Andi Offset.

Setyowati, Eni, dan Soepatini. 2004. Analisis Faktor-faktor yang Mempengaruhi Nilai Tukar Rupiah terhadap Dollar AS dengan Pendekatan Neraca Pembayaran (Pendekatan Engle Granger Error Correction Model). Jurnal Ekonomi Pembangunan FE UMS Vol. 5, No. 2. Desember, 2004.
Sukirno, Sadono, 2000. Makro Ekonomi Modern Perkembangan Pemikiran dari Klasik Hingga Keynesian Baru, Jakarta: PT. Raja Grafindo Persada.

Susilo. Y. Sri, Sigit Triandaru, A. Totok Budi Santoso, 2000. Bank dan Lembaga Keuangan lain, Jakarta: Salemba Empat,

Utomo, Yuni Pribadi. 2005. Penurunan Model Estimasi Jangka Pendek ECM. Surakarta (makalah tidak diterbitkan).

Yuliati, Sri Handaru, dan Handoyo Prasetyo. 1998. Dasar-dasar Manajemen Keuangan Internasional. Yogyakarta: Andi. 


\title{
PEDOMAN PENULISAN \\ JURNAL EKONOMI PEMBANGUNAN FAKULTAS EKONOMI UNIVERSITAS MUHAMMADIYAH SURAKARTA
}

Terbit: 2 kali dalam setahun pada bulan Juni dan Desember

\author{
Akreditasi Jurnal: \\ KEPUTUSAN DIREKTUR JENDERAL PENDIDIKAN TINGGI \\ KEMENTERIAN PENDIDIKAN NASIONAL NOMOR: 51/DIKTI/Kep./2010 \\ (masa berlaku Juni 2010 s.d Juni 2013)
}

1. Artikel ditulis dengan bahasa Indonesia atau bahasa Inggris dalam bidang kajian masalah ekonomi dan pembangunan.

2. Substansi artikel diharapkan sejalan dengan Panduan Akreditasi Berkala Ilmiah 2006, yang diterbitkan Direktorat Penelitian dan Pengabdian kepada Masyarakat (DP2M) Direktorat Jenderal Pendidikan Tinggi Republik Indonesia).

3. Artikel ditulis dengan kaidah tata bahasa Inggris ataupun bahasa Indonesia yang baik dan benar.

4. Sistematika Penulisan

Sistematika penjenjangan atau peringkat judul artikel dan bagian-bagiannya dilakukan dengan cara berikut:

(1) Judul ditulis dengan huruf besar semua, di bagian tengah atas pada halaman pertama

(2) Sub Bab Peringkat 1 ditulis dengan huruf pertama besar semua di tengah/center

(3) Sub Bab Peringkat 2 ditulis dengan huruf besar-kecil rata tepi kiri

- Sistematika artikel hasil penelitian adalah: judul; nama penulis (tanpa gelar akademik); nama dan alamat institusi, alamat e-mail penulis, abstrak (maksimum 150 kata) yang berisi tujuan, metode, dan hasil penelitian; kata kunci (4-5 kata kunci); pendahuluan (tanpa ada subjudul) yang berisi latar belakang, sedikit tinjauan pustaka, dan tujuan penelitian; metode; hasil penelitian dan pembahasan; kesimpulan; daftar rujukan (hanya memuat sumber-sumber yang dirujuk).

\section{JUDUL UTAMA:}

\section{Sub Judul}

Penulis $1^{1}$ dan Penulis $2^{2}$

${ }^{1}$ Nama instansi/lembaga Penulis 1

Alamat lengkap instansi penulis, nomor telepon instansi penulis

${ }^{2}$ Nama instansi/lembaga Penulis 2

Alamat lengkap instansi penulis, nomor telepon instansi penulis

(jika nama instansi penulis 1 dan 2 sama, cukup ditulis satu saja)

E-mail penulis 1 dan 2:

Abstrak: Abstrak dalam bahasa Indonesia (125 - 150 kata)

Kata kunci: 4 - 5 katal frase

Abstract: Abstract in english (125 - 150 words)

Keywords: $4-5$ words/ phrase

\section{PENDAHULUAN}

(berisi latar belakang, sekilas tinjauan pustaka, dan tujuan penelitian, yang dimasukkan dalam paragraf paragraf bukan dalam bentuk subbab)

METODE PENELITIAN

Subbab

Subbab

...

\section{HASIL ANALISIS DAN PEMBAHASAN}

Pedoman Penulisan Jurnal Ekonomi Pembangunan FE Universitas Muhammadiyah Surakarta 


\title{
Subbab
}

\section{KESIMPULAN \\ DAFTAR PUSTAKA}

- Sistematika artikel hasil pemikiran adalah: judul; nama penulis (tanpa gelar akademik); nama dan alamat institusi, alamat e-mail penulis, abstrak (maksimum 150 kata); kata-kata kunci (4-5 kata kunci); pendahuluan (tanpa ada subjudul) yang berisi latar belakang dan tujuan atau ruang lingkup tulisan; bahasan utama (dapat dibagi ke dalam beberapa sub-judul); penutup atau kesimpulan; daftar rujukan (hanya memuat sumber-sumber yang dirujuk).

\section{JUDUL UTAMA: \\ Sub Judul}

Penulis $1^{1}$ dan Penulis $2^{2}$

${ }^{1}$ Nama instansi/lembaga Penulis 1

Alamat lengkap instansi penulis, nomor telepon instansi penulis

${ }^{2}$ Nama instansi/lembaga Penulis 2

Alamat lengkap instansi penulis, nomor telepon instansi penulis

(jika nama instansi penulis 1 dan 2 sama, cukup ditulis satu saja)

E-mail penulis 1 dan 2 :

\author{
Abstrak: Abstrak dalam bahasa Indonesia (125--150 kata) \\ Kata kunci: 4 - 5 katal frase \\ Abstract: Abstract in english (125 - 150 words) \\ Keywords: $4-5$ words/ phrase

\section{PENDAHULUAN PEMBAHASAN \\ KESIMPULAN} \\ DAFTAR PUSTAKA
}

5. Artikel diketik pada kertas kwarto berkualitas baik. Dibuat sesingkat mungkin sesuai dengan subyek dan metode penelitian (bila naskah tersebut ringkasan penelitian), biasanya 20-25 halaman dengan spasi satu, untuk kutipan paragraf langsung diindent (tidak termasuk daftar pustaka).

6. Marjin atas, bawah, dan samping harus dibuat paling tidak satu inci.

7. Abstrak, ditulis satu paragraf sebelum isi naskah. Abstrak dalam dua bahasa yaitu bahasa Indonesia dan bahasa Inggris. Abstrak tidak memuat uraian matematis, dan mencakup esensi utuh penelitian, metode dan pentingnya temuan dan saran atau kontribusi penelitian.

8. $\quad$ a. Penulisan numbering diintegrasikan dalam paragraf, contohnya:

Tujuan dilakukannya penelitian ini adalah: (1) Untuk mengetahui apakah CSR berpengaruh positif terhadap nilai perusahaan, (2) Untuk mengetahui apakah persentase kepemilikan manajemen berperan sebagai variabel moderating dalam hubungan antara CSR dengan nilai perusahaan, dan (3) Untuk mengetahui apakah tipe industri berperan sebagai variabel moderating dalam hubungan antara CSR dengan nilai perusahaan?

b. Penulisan bullet juga diintegrasikan dalam paragraf dengan menggunakan tanda koma pada antarkata/kalimat tanpa bullet.

9. Tabel dan gambar, untuk tabel dan gambar (grafik) sebagai lampiran dicantumkan pada halaman sesudah teks. Sedangkan tabel atau gambar baik di dalam naskah maupun bukan harus diberi nomor urut.

- Tabel atau gambar harus disertai judul. Judul tabel diletakkan di atas tabel sedangkan judul gambar diletakkan di bawah gambar.

Pedoman Penulisan Jurnal Ekonomi Pembangunan FE Universitas Muhammadiyah Surakarta 
- Sumber acuan tabel atau gambar dicantumkan di bawah tabel atau gambar.

- Garis tabel yang dimunculkan hanya pada bagian header dan garis bagian paling bawah tabel sedangkan untuk garis-garis vertikal pemisah kolom tidak dimunculkan.

Contoh: Tabel

Tabel 1. Bentuk-bentuk Mobilitas Penduduk

\begin{tabular}{llll}
\hline No & Bentuk Mobilitas & Batas Wilayah & Batas Waktu \\
\hline 1. & Ulang-alik (commuting) & Dukuh (dusun) & 6 jam atau lebih dan kembali pada hari yang sama \\
2. & Menginap/mondok di daerah tujuan & Dukuh (dusun) & Lebih dari satu hari tetapi kurang dari 6 bulan \\
3. & Permanen/menetap di daerah tujuan & Dukuh (dusun) & 6 bulan atau lebih menetap di daerah tujuan \\
\hline
\end{tabular}

Sumber: Ida Bagoes, 2000

\section{Contoh: Gambar}

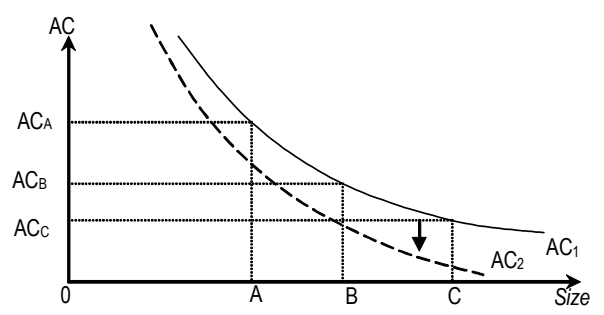

Sumber: Saunders (1997: 291)

Gambar 2. Dampak Peningkatan Teknologi

10. Cara penulisan rumus, Persamaan-persamaan yang digunakan disusun pada baris terpisah dan diberi nomor secara berurutan dalam parentheses (justify) dan diletakkan pada margin kanan sejajar dengan baris tersebut. Contoh:

$\mathrm{wt}=\mathrm{f}\left(\mathrm{y}_{\mathrm{t}}, \mathrm{k}_{\mathrm{t}}, \mathrm{w}_{\mathrm{t}-1}\right)$

11. Keterangan Rumus ditulis dalam satu paragraf tanpa menggunakan simbol sama dengan (=), masingmasing keterangan notasi rumus dipisahkan dengan koma. Contoh:

Dimana $\mathbf{w}$ adalah upah nominal, $\mathbf{y t}$ adalah produktivitas pekerja, kt adalah intensitas modal, $\mathbf{w}_{\mathbf{t}-\mathbf{1}}$ adalah tingkat upah periode sebelumnya.

12. Perujukan sumber acuan di dalam teks dengan menggunakan nama akhir dan tahun. Kemudian bila merujuk pada halaman tertentu, penyebutan halaman setelah penyebutan tahun dengan dipisah titik dua. Untuk karya terjemahan dilakukan dengan cara menyebutkan nama pengarang aslinya.

Contoh:

- Yuni (2008: 23) memandang bahwa .....

- Fatimah dan Daryono (1997) menunjukkan adanya ....

- Didit dkk (2007) berkesimpulan bahwa....

- Untuk meningkatkan perekonomi daerah .... (Yuni, Triyono, dan Agung Riyardi, 2009).

- Maya (2009) berpendapat bahwa ....

13. Setiap kutipan, baik langsung maupun tidak langsung, harus diikuti sumbernya (lihat poin no. 10) dan dicantumkan juga dalam daftar pustaka. Contoh:

Di dalam paragraf isi tercantum kutipan dari: Buiter (2007:15) berpendapat bahwa...

Maka dalam daftar pustaka harus ada sumber referensinya seperti berikut:

Buiter, W. H., (2002). The Fiscal Theory of the Price Level: A Critique, Economic Journal, 112(127): 459-480.

Pedoman Penulisan Jurnal Ekonomi Pembangunan FE Universitas Muhammadiyah Surakarta 
14. Sedapat mungkin pustaka-pustaka yang dijadikan rujukan adalah pustaka yang diterbitkan 10 tahun terakhir dan diutamakan dari jurnal ilmiah.

15. Unsur yang ditulis dalam daftar pustaka secara berturut-turut meliputi: (1) nama akhir pengarang, nama awal, nama tengah, tanpa gelar akademik, (2) tahun penerbitan, (3) judul termasuk subjudul, (4) tempat penerbitan, (5) nama penerbit.

Contoh cara penulisan:

a. Format rujukan dari buku: Nama pengarang, (tahun), Judul Buku, edisi, Kota penerbit, Nama penerbit. Jika penulis sebagai editor tunggal, ditulis (Ed.) di belakang namanya. Ditulis (Eds.) jika editornya lebih dari satu orang. Kemudian bila pengarang lebih dari tiga orang, dituliskan nama pengarang pertama dan yang lain disingkat 'dkk' (pengarang domestik) atau 'et.al.' (pengarang asing).

Enders, W., (2004), Applied Econometric Time Series, Second edition, New York: John Wiley \& Sony Inc. Purnomo, Didit (Ed.). (2005). The Role of Macroeconomic Factors in Growth. Surakarta: Penerbit Muhamadiyah University Press.

b. Format rujukan dari artikel dalam buku ditulis: Nama editor (Ed.), (tahun), Judul tulisan/karangan. Judul buku, hlm atau pp., kota penerbit: nama penerbit

Daryono (Ed.). (2005). Concept of Fiscal Decentralization and Worldwide Overview (hlm. 12-25). Surakarta: Penerbit Muhammadiyah University Press.

c. Format rujukan dari artikel dalam jurnal/majalah/koran: Nama pengarang (tahun). judul tulisan/ karangan. Nama jurnal/majalah/koran, hlm atau pp., volume (nomor), halaman. Jika rujukan koran tanpa penulis, nama koran ditulis diawal.

Rodden, J., (2002). The dilemma of Fiscal Federalism: Grants and Fiscal Performance arround the World. American Journal of Political Science, 46 (3): 670-687.

Triyono (2008). Perimbangan Keuangan Pusat dan Daerah Sebagai Pelaksanaan Desentralisasi Fiskal Efek. Warta Ekonomi, Vol. 4, Agustus: 46-48.

Haryanto, S., (2007, 13 November). Desentralisasi Fiskal dan Pembangunan Ekonomi. Harian Jakarta, hlm.4.

Harian Jogjakarta, (2007, 1 April). Hubungan Keuangan Pusat-Daerah di Indonesia. hlm. 4.

d. Format rujukan dari internet, tanggal akses dicantumkan.

Setyowati, E.,. Keuangan Publik dan Sistem Harga. http://www.ekonomipublik.com/akt/pdf/akt452.pdf.

Diakses tanggal 27 Mei 2009.

\section{Pengiriman Artikel}

1. Artikel dikirimkan sebanyak 2 eksemplar hardcopy, dan softcopy berupa file. File bisa dikirim melalui email jepums@yahoo.co.id atau dalam media cd.

2. Artikel yang dikirim wajib dilampiri biodata ringkas pendidikan termasuk catatan riwayat karya-karya ilmiah sebelumnya yang pernah dipublikasikan, insitusi dan alamatnya, nomor telpon kontak atau e-mail penulis.

3. Penulis yang menyerahkan artikelnya kepada editor atau penerbit, harus menjamin bahwa naskah yang diajukan tidak melanggar hak cipta, belum dipublikasikan atau telah diterima untuk dipublikasi oleh jurnal lainnya.

4. Kepastian pemuatan atau penolakan naskah akan diberitahukan secara tertulis. Penulis yang artikelnya dimuat mendapatkan jurnal tersebut. Artikel yang tidak dimuat tidak akan dikembalikan.

\section{Alamat Redaksi Jurnal Ekonomi Pembangunan Fakultas Ekonomi Universitas Muhammadiyah Surakarta: \\ Redaksi Jurnal Ekonomi Pembangunan Fakultas Ekonomi Universitas Muhammadiyah Surakarta Jalan A. Yani Tromol Pos I Pabelan SURAKARTA 57102 Telp. 0271-717417 psw 229}

Pedoman Penulisan Jurnal Ekonomi Pembangunan FE Universitas Muhammadiyah Surakarta 
TENTANG JURNAL:

\title{
JURNAL EKONOMI PEMBANGUNAN
}

Kajian Masalah Ekonomi dan Pembangunan

ISSN 1411- 6081

\author{
Pimpinan Redaksi \\ Didit Purnomo
}

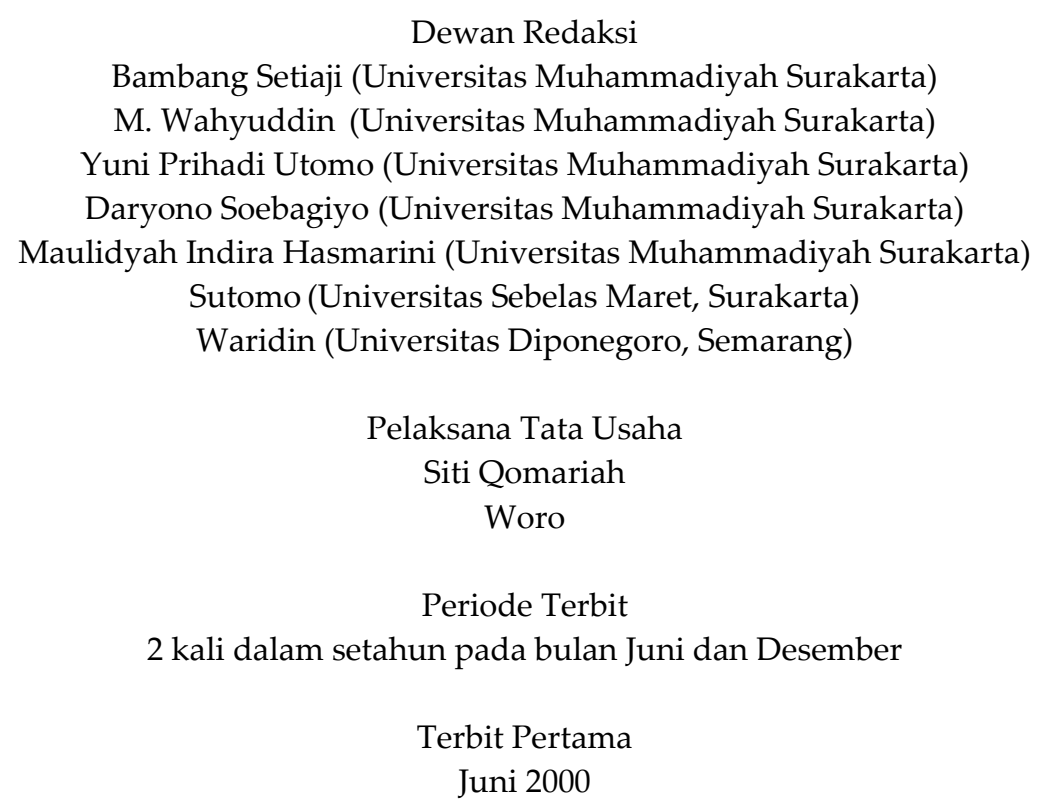

Jurnal EKONOMI PEMBANGUNAN merupakan jurnal ilmiah yang berisikan hasil penelitian dan kajian teoritis mengenai masalah-masalah ekonomi dan pembangunan, khususnya di Indonesia. Diterbitkan oleh Balai Penelitian dan Pengembangan Ekonomi Fakultas Ekonomi Universitas Muhammadiyah Surakarta.

Redaksi menerima sumbangan tulisan yang belum pernah diterbitkan atau dalam proses terbit oleh media lain. Naskah diketik di atas kertas HVS kuarto spasi satu sepanjang lebih kurang 20-25 halaman, dengan format seperti tercantum pada prasyarat naskah jurnal EKONOMI PEMBANGUNAN di halaman belakang. Naskah yang masuk akan dievaluasi dan disunting untuk keseragaman format dan tata cara lainnya.

Alamat Penyunting dan Tata Usaha: Subag Tata Usaha Fakultas Ekonomi Universitas Muhammadiyah Surakarta, Jl. A. Yani, Tromol Pos 1, Pabelan, Surakarta 57102; Telpon (0271) 717417 psw 229,

E-mail: jepums@yahoo.co.id

Website: http://www.ums.ac.id atau http://www.paradejurnal.wordpress.com

Simak informasi jurnal: http://www.paradejurnal.wordpress.com

Admin: Mirat Sidharta. SE

Pedoman Penulisan Jurnal Ekonomi Pembangunan FE Universitas Muhammadiyah Surakarta 